\title{
Comparative Electropherograms of Muscle Proteins of Three Species of Lizard Fishes referable to the Genus Saurida
}

\author{
Nobuhiko TANIGUCHI* \\ (Received June 16, 1969)
}

In 1935, the lizard fishes distributing all over the world were reviewed by NORMAN ${ }^{11}$, who recognized nine species in the genus Saurida. Of nine species, at least three ones, S. undosquamis (RICHARDSON), S. tumbil (BLOCH) and S. elongata (TemminCK et SCHLEGEL) were found from the waters of Japan and its adjacent regions by some ichthyologists such as TAtara ${ }^{2)}$, Matsubara and IWA $^{3 \text { ) }}$. But the classification of this group was not yet so clear so far as the external and internal characters alone were used as criteria.

In the studies of biochemical systematics of fishes, composition of the muscle proteins has often been used as a criterion for identification of some closely related fish ss, and for analysis of intra-generic and intra-familial relationships. ${ }^{4-15}$ As to the electrophoretic methods, starch-gel electrophoresis has been often used as a tool for separation of muscle proteins. Although the cellulose acetate electrophoresis was used for the separation of elasmobranch serum proteins by Hess and SMITH ${ }^{16)}$, it has scarcely been employed to analysis of the composition of teleostean fish muscle proteins, as far as the author's knowledge is concerned. The aim of the present investigation is to describe the differentiation of three Japanese species of the genus Saurida based on the property of muscle proteins by means of the handy method of cellulose acetate electrophoresis. The author has found that the fish muscle proteins of the lizard fish stored at $-20^{\circ} \mathrm{C}$ are very stable in composition, showing the species specificity.

The author acknowledges to Dr. Norio SUzukı of Kyoto University for his leadership of the experimental techniques and invaluable comments, and to Professor Akira OCHIAI of Kochi University for his invaluable comments and reading of the manuscript.

\section{Materials and Methods}

The samples of these three species were collected from the waters of Maizuru, Kyoto Prefecture; Yoshimi, Yamaguchi Prefecture; Akashi, Hyogo Prefecture; and East China Sea: S. undosquamis; 7 specimens, $26.5-34.5 \mathrm{~cm}$ in folk length, collected at Maizuru, in Sept. 1967, 2 specimens, 20.6 and $22.2 \mathrm{~cm}$, at Yoshimi, Nov. 1967. S. tumbil; 10 speciemens, $27.0-34.0 \mathrm{~cm}$, in East China Sea, July 1967, 2 specimens, 36.6 and $38.0 \mathrm{~cm}$, at Maizuru, June 1967, 1 specimen, $42.5 \mathrm{~cm}$, at Maizuru, Sept. 1967, 1 specimens, $54.5 \mathrm{~cm}$,

* Department of Cultural Fisheries, Faculty of Agriculture, Kochi University, Nangoku, Kochi Pref., Japan. (谷口順彦：高知大学農学部载培漁業学科) 
at Maizuru, June 1968. S. elongata; 7 specimens, $27.0-38.0 \mathrm{~cm}$, at Maizuru, Aug. 1967, 1 specimen, $34.0 \mathrm{~cm}$, Maizuru, Aug. 1967, 2 specimens, size unknown, at Akashi, Nov. 1967.

The samples were stored at $-20^{\circ} \mathrm{C}$ in a deep freezer for 1 to 45 days after collection. The muscle extract for electrophoresis was prepared by the following methods: a small quantity of muscle, usually $5 \mathrm{gr}$, obtained from a part of trunk under the first dorsal fin, was homogenized by a Waring blendor at room temperature, with $10 \mathrm{ml}$ of the solution consisting of the same volumes of glycerol and Veronal buffer solution with $\mathrm{pH} 8.6$ and ionic strength of 0.06 . The glycerol was added to maintain the stability of the resulting solution. The homogenized material was centrifuged for 15 minutes at $10,000 \mathrm{rev} / \mathrm{min}$ $(12,000 \mathrm{G})$, and then the supernatant fraction was used as sample for cellulose acetate electrophoresis. The cellulose acetate electrophoresis was principally operated by OGAWA's method ${ }^{17)}$. Electrophoretic apparatus manufactured by Jôko Sangyo Co., Ltd., was employed for the separation of muscle extracts. The cellulose acetate membrane used here was a product, "Separax" made by Fuji Shashin Film Co., Ltd. The electrophoresis was carried out for 2 hours with current of $0.3 \mathrm{~mA}$ per $1 \mathrm{~cm}$ width of sheet. Veronal buffer solution for electrophoresis was changed each time in a series of experiments to compare electropherograms on the same condition. Muscle extracts were introduced carefully on the surface of sheet by means of $0.0008 \times 5$ ultra micropipette. Muscle proteins were stained with Ponceau 3R. The sheet of cellulose acetate was made transparent with the liquid paraffin, and traced with a Ozumor 7 Atago self-recording densitometer manufactured by Atago Optical Works Co., Ltd. The subsequent densitometric patterns were analysed for the quantitative and qualitative comparisons of muscle proteins.

\section{Results}

The stability of electropherograms of specimens stored at $-20^{\circ} \mathrm{C}$ : The stability of densitometric patterns of muscle proteins of $S$. tumbil was tested by the specimens stored at $-20^{\circ} \mathrm{C}$ for 1 to 45 days (Fig. 1), the muscle extracts being kept at $0-4^{\circ} \mathrm{C}$ for various periods (Table 1). The densitometric pattern has mainly four peaks, which were named Nos. 1-4 respectively from the anode side. The component existing at origin was excluded, because the variation was observed in the percentage of the component which is considered to be affected by the technical factors. There were little differences in the percentages and mobilities among the samples stored for various periods (Fig. 1, Table 1). Therefore, it may be concluded that the specimens stored at $-20^{\circ} \mathrm{C}$ are probably available until at least 45 days after sampling, and the protein samples extracted by the salt solution of low ionic strength also can be used for the electrophoretic investigations until at least 15 days at $0-4^{\circ} \mathrm{C}$ after being extracted. 
Table 1. Change of electrophoretic pattern of muscle proteins of $S$. tumbil during storage. Samples were stored at $-20^{\circ} \mathrm{C}$ and protein extract at $0-4^{\circ} \mathrm{C}$.

\begin{tabular}{c|c|c|cccc}
\hline \multirow{2}{*}{$\begin{array}{c}\text { Date of } \\
\text { sampling }\end{array}$} & $\begin{array}{c}\text { Date of } \\
\text { extracting }\end{array}$ & $\begin{array}{c}\text { Date of } \\
\text { experiment }\end{array}$ & \multicolumn{3}{|c}{ Percentage in densitometric pattern } \\
\cline { 4 - 6 } & & Comp. 1 & Comp. 2 & Comp. 3 & Comp. 4 \\
\hline 15th, June & 15th, June & 15th, June & 4.0 & 31.7 & 44.4 & 19.8 \\
15th, June & 22th, June & 22th, June & 6.3 & 29.3 & 41.8 & 22.6 \\
15th, June & 29th, June & 29th, June & 9.4 & 27.5 & 43.3 & 19.9 \\
15th, June & 29th, June & 5th, July & 7.2 & 26.4 & 44.8 & 21.6 \\
15th, June & 29th, June & 12th, July & 5.7 & 26.2 & 44.0 & 24.1 \\
15th, June & 5th, July & 5th, July & 8.8 & 26.7 & 43.0 & 21.1 \\
15th, June & 28th, July & 28th, July & 8.5 & 29.7 & 41.5 & 20.3 \\
\hline
\end{tabular}

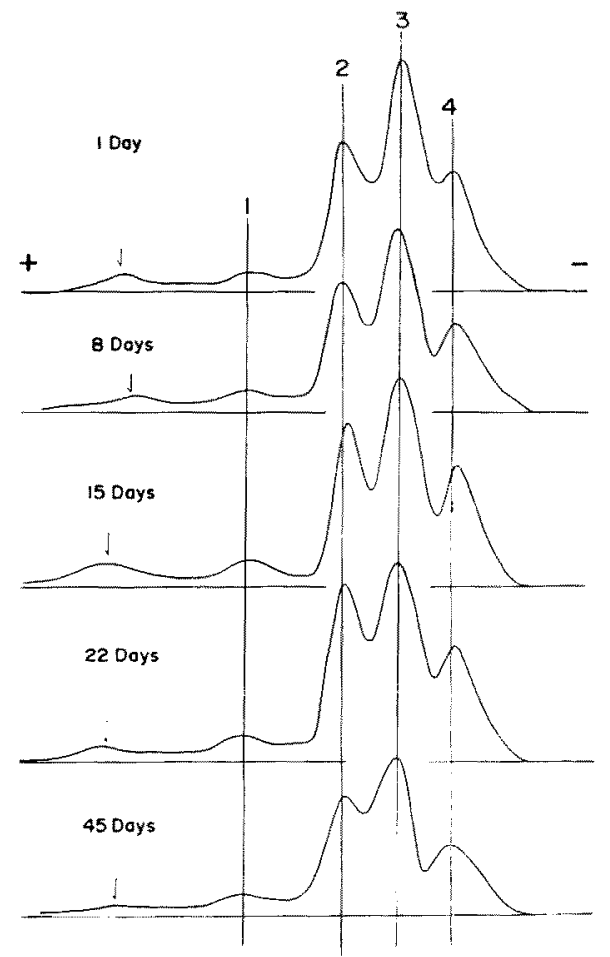

Fig. 1. Densitometric patterns of muscle proteins of $S$. tumbil stored at $-20^{\circ} \mathrm{C}$ for various periods. Arrows show the origin.

Comparison of electropherograms among three species: The electrophoretic patterns were examined here from three aspects, such as the number of components, and the mobility and percentage of each component. The number of components was 8 in S. elongata, 7 in $S$. tumbil and 5 in $S$. undosquamis as shown schematically in Fig. 2. In order to compare the percentage of each component, these components appearing in electropherograms were conveniently grouped into three parts which were designated here 


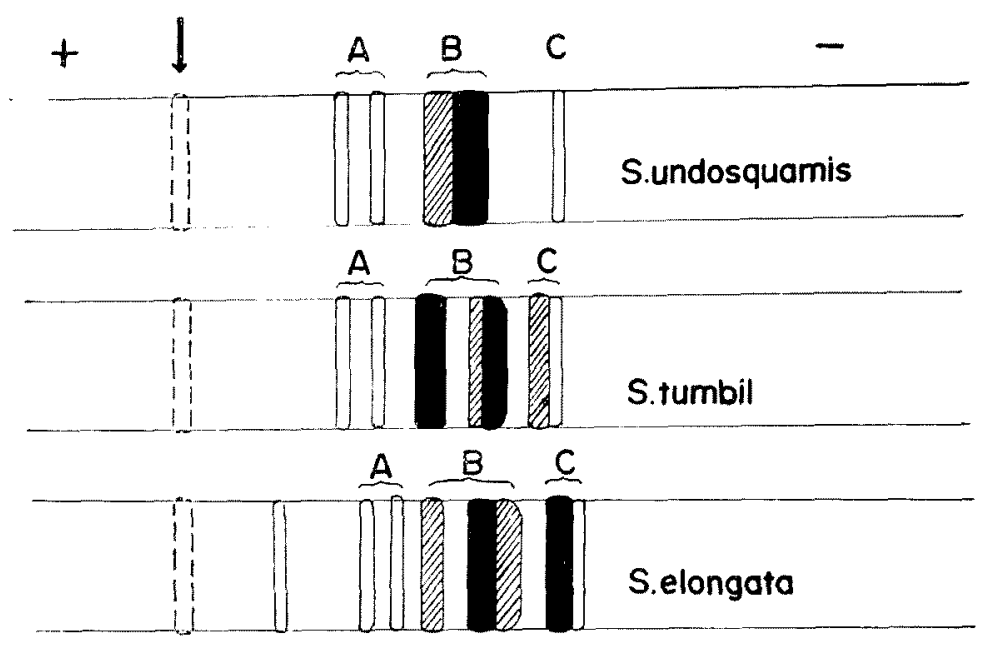

Fig. 2. Schematic electrophoretic patterns of muscle proteins of three lizard fishes. Arrow shows the origin.
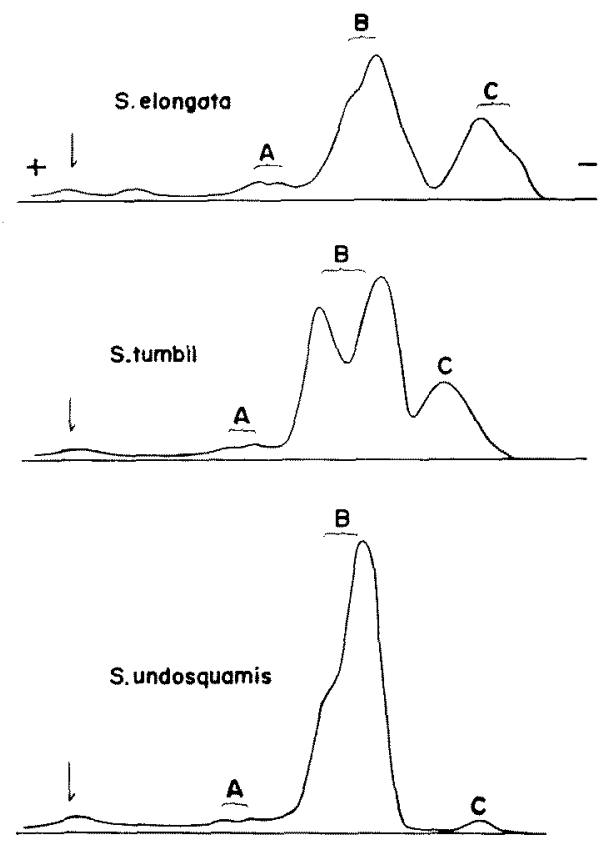

Fig. 3. Densitometric patterns of muscle proteins of three lizard fishes. Percentages of three parts $\mathrm{A}, \mathrm{B}$ and $\mathrm{C}$ were calculated from those patterns. Arrows show the origin. as $\mathrm{A}, \mathrm{B}$ and $\mathrm{C}$ respectively from the anode side (Fig. 2). The typical densitometric patterns of three species are shown in Fig. 3. The distinct differences in the electrophoretic patterns were recognized among these three species. The percentage of the parts of each species was useful in comparing the properties of species and in tracing the tendency of inter-specific variations. The percentages of part B ranged from $56.8 \%$ to $68.9 \%$ in 10 samples of S. elongata, from $71.9 \%$ to $81.0 \%$ in 15 samples of $S$. tumbil and from $85.3 \%$ to $95.3 \%$ in 9 samples of $S$. undosquamis respectively. The average value of part $B$ was small in S. elongata $(63.1 \%)$, large in S. undosquamis $(89.9 \%$ ) and intermediate in $S$. tumbil $(76.4 \%)$. The percentages of part $\mathrm{C}$ ranged from $25.6 \%$ to $35.7 \%$ in $S$. elongata, from $12.0 \%$ to $20.9 \%$ in S. tumbil and from $0.4 \%$ to $4.2 \%$ in S. undosquamis. The average value of part C was small in S. undosquamis $(2.1 \%)$, large in S. elongata $(29.8 \%)$ and intermediate in S. tumbil $(15.6 \%)$. In identifying three species of the lizard 
fishes, the range of percentages of part $B$ or $C$ is useful because it does not overlap among species treated.

\section{Discussion}

Based on their elaborate works, TSUYUKi et al. ${ }^{11 /}$ stated that muscle protein (myogen) patterns were virtually unaffected by factors other than genetic factor, showing species specificity. YAMASHITA ${ }^{18)}$ showed that the electrophoretic patterns of serum protein of rock fishes are reproducible within only 3 days after sampling and differentiation of peaks lessened with the prolongation of preservation. The author, however, observed here that the electrophoretic patterns of the lizard fish muscle protein were very stable for at least 45 days when the muscle was kept at $-20^{\circ} \mathrm{C}$. Judging from the result obtained above, the muscle protein may be stored longer than 45 days after sampling, without showing any change in electrophoretic pattern. Therefore, it is evident that the electrophoretic characters of the muscle proteins, such as the number of components and the percentage and mobility of each component are more reliable than those of the serum protein, and available for the study of biochemical systematics.

The author found the distinct inter-specific differentiation in the electrophoretic patterns of muscle proteins of three lizard fishes. S. undosquamis remarkably differs from $S$. elongata, and $S$. tumbil is intermediate between those two species. This tendency well accords to that of divergence of the morphometrical data given by MATSUBARA and IwAI $^{3)}$ (Table 2).

Table 2. Electrophoretic and morphometrical characters, the latter of which were cited from Matsubara and IwaI in 1951, of three lizard fishes.

\begin{tabular}{l|c|c|c|c}
\hline \multicolumn{1}{c|}{ Species } & $\begin{array}{c}\text { Percentage } \\
\text { of part B }\end{array}$ & $\begin{array}{c}\text { No. of } \\
\text { components }\end{array}$ & $\begin{array}{c}\text { Scales in } \\
\text { lateral line }\end{array}$ & $\begin{array}{c}\text { No. of } \\
\text { Vertebrae }\end{array}$ \\
\hline S. elongata & 63.1 & 8 & 65 & 60 \\
S. tumbil & 76.4 & 7 & 58 & 53 \\
S. undosquamis & 89.9 & 5 & 51 & 48 \\
\hline
\end{tabular}

Accordingto TATARA ${ }^{21}$, S. elongata is divided into two subpopulations, the one being provided with less vertebrae, 58 in mode and the another with more vertebrae, 63. The specimens examined in this study belong to the former group. Lately, MATSUBARA and OCHIAl $^{19)}$ expressed an opinion that the difference observed between these two groups is suited at the specific level. In the near future, the author wants to compare these two groups by the electrophoretic method to solve this problem.

\section{Summary}

The cellulose acetate electrophoretic patterns of three species of lizard fishes, Saurida 
undosquamis, S. tumbil and S. elongata were observed. The property of muscle proteins soluble in salt solution of low ionic strength in each species was analyzed for the mobility and percentage of each component, and the number of components in the electrophoretic pattern. Although the differentiation among these three species was distinct, S. undosquamis was more similar to $S$. tumbil than to $S$. elongata, and $S$. tumbil was intermediate between $S$. undosquamis and $S$. elongata in this character. This trend was parallel with that of the morphological evidence.

It is also verified that electrophoretic patterns of muscle proteins were very stable for at least 45 days, when the specimens were stored at $-20^{\circ} \mathrm{C}$.

\section{References}

1) J. R. Norman: Proc. Zool. Soc. London, Part 1, 99-135 (1935).

2) K. Tatara: Tokai Kokai Sokouo-Shigen Chôsa Kenkyu-shi, 1. (1949).

3) K. Matsubara and T. IWai: Mem. Coll. Agri. Kyoto Univ., 59, 19-30 (1951).

4) J. J. Connell: Biochem. J., 55, 378-388 (1953).

5) J. R. Dingle, D. E. Engles, and J. M. Neelin: J. Fish. Res. Bd. Canada, 12, 75-84 (1955).

6) H. A. Lillevic and C. L. Schloemer: Science, 134, 2042-2043 (1961).

7) L. Nyman: Ann. Acad. Reg. Sci. Upsal., 9, 1-18 (1965).

8) L. Nyman: Hereditas, 53, 117-126 (1965).

9) R. R. Thomspon: J. Assoc. Offic. Agri. Chemists, 43, 763-764 (1960).

10) H. Tsuyuki and E. Roberts: J. Fish. Res. Bd. Canada, 20(1), 101-104 (1963).

11) H. Tsuyuki, E. Roberts, and W. E. VANstone: ibid., 22(1), 203-213 (1965).

12) H. Tsuyuki and E. Roberts: ibid., 23(1), 101-107 (1966).

13) H. Tsuyuki, J. F. Uthe, E. Roberts and W. Clarke: ibid., 23(10), 1599-1606 (1966).

14) H. TSuyuki, E. Roberts and R. H. Kerr: ibid., 24(2), 299-304 (1967).

15) J. F. Uthe, E. Roberts, L. W. Clarke and H. Tsuyuki: ibid., 23(11), 1663-1671 (1966).

16) P. W. Hess and R. A. Smith: Trans. Amer. Fish. Soc. 96, 131-133 (1967).

17) Y. OGaWA: Metabolism and Disease, 2(2), 514-532 (1965).

18) H. Yamashita: This Bull., 34(12), 1059-1065 (1968).

19) K. Matsubara and A. OChiai: Gyorui-Gaku (II), 958 pp., Kôseisha-Kôseikaku, Tokyo (1965). (In Japanese) 